\title{
Features of use of unlawful kaolin for the manufacture of a cement clinker
}

\author{
M.Yu. Tsybenko ${ }^{1}$, L.P. Chernyak ${ }^{1}$, V.G. Salnik ${ }^{2}$, N.O. Dorogan ${ }^{1}$ \\ Kyiv, 03056, Ukraine \\ Tel.: +380672985775 \\ E-mail: lpchernyak@ukr.net \\ 2 - Corporation "Ukrbudmaterialy”, str. Pavlivska, Bldg. 29, Kyiv, 01054, Ukraine \\ Tel.: +380673826033 \\ E-mail:svgnomad@ukr.net
}

1 - National Technical University of Ukraine “Igor Sikorsky Kyiv Polytechnic Institute”, aven. Peremogy, 37, Bldg. 21,

Article info: received 11.04.2018, revised 18.05.2018, accepted 22.06.2018

Tsybenko, M.Yu., Chernyak, L.P., Salnik, V.G., Dorogan, N.O. (2018) Features of use of unlawful kaolin for the manufacture of a cement clincer 2(39), doi: 10.26909/csl.2.2018.1

Results over of research of the silicate systems of carbonate raw material with the varieties of clay component for making of cement clinker. The features of the chemical-mineralogical composition, phase transformations during burning and astringent properties of clinker are shown when unenriched kaolin and fly ash are used as alumina-silica-containing components of the initial raw material mixture.

In the chemical technology of hydraulic mineral astringents, clay raw material serves, first of all, as a source of $\mathrm{SiO}_{2}$, $\mathrm{Al}_{2} \mathrm{O}_{3}, \mathrm{Fe}_{2} \mathrm{O}_{3}$ oxides, which must form from $\mathrm{CaO}$ during the baking of crystalline phases of silicates, aluminates and calcium aluminferrite, with the development of which impart the properties of the product of production.

In turn, the above oxides arise in the process of technology during the heat treatment of raw mixtures due to the destruction of the lattice of rock-forming minerals. Hence the obvious dependence of the number and reactivity of oxides on the chemical and mineralogical composition of clay raw material, which, according to essential differences, is classified into a number of groups. Deepening of scientific ideas about this dependence can become an additional factor for improving the intensification of the technology of silicate binders, which became the subject of research in the given work.

The chemical and mineralogical composition of the clay component of raw materials for the production of clinker and cement based on it is an important factor in the structure of the binder material at the stages of the technological process and the determination of the properties of the final product.

Taking into account the peculiarities of the composition of unbleached kaolin (high content of kaolinite, quartz, feldspar), the feasibility of its application in the production of cement for clinker production is related to the possibility of adjusting the kinetics and the direction of phase transformations during the burning of the material.

From the point of view of resource conservation and technology, the complex application of aluminum and silicon-containing raw materials components of natural (unaffected kaolin) and man-made (fly ash) origin is shown.

Deepening of scientific ideas about this dependence can become an additional factor for improving the intensification of the technology of silicate binders, which became the subject of research in the given work.

Key words: silicate systems, clinker, kaolin, clay, mineralogical composition.

\section{Особливості використання незбагаченого каоліну для виготовлення цементного клінкеру}

\author{
М.Ю. Цибенко ${ }^{1}$, Л.П. Черняк ${ }^{1}$, В.Г. Сальник ${ }^{2}$, Н.О. Дорогань ${ }^{1}$ \\ ${ }^{1}$ - Національний технічний університет Украӥни “Київький політехнічний інститут”, Київ, Україна \\ ${ }^{2}$ - Корпорачія «Укрбудматеріали», Київ, Украӥна
}

Наведені результати досліджень силікатних систем карбонатної сировини з різновидами глинистого компоненту для виготовлення цементного клінкеру. Показані особливості хіміко-мінералогічного складу, фазових 
перетворень при випалі та в’яжучих властивостей клінкеру при використанні незбагаченого каоліну та золи виносу як алюмо- і кремнеземвмісних компонентів вихідної сировинної суміші.

Поглиблення наукових уявлень про вказану залежність може стати додатковим фактором вдосконалення ті інтенсифікації технології силікатних в'яжучих речовин, що стало предметом дослідження в поданій роботі.

\section{Вступ}

Глиниста сировина віддавна використовується для виготовлення силікатних матеріалів і виробів побутового та технічного призначення $[1,2]$. В хімічній технології гідравлічних мінеральних в'яжучих речовин глиниста сировина слугує, перш за все, джерелом оксидів $\mathrm{SiO}_{2}, \mathrm{Al}_{2} \mathrm{O}_{3}, \mathrm{Fe}_{2} \mathrm{O}_{3}$, що мають утворювати з $\mathrm{CaO}$ при випалі кристалічні фази силікатів, алюмінатів і алюмоферриту кальцію, з розвитком яких пов'язують властивості продукту виробництва [3 - 7].

У свою чергу, вказані вище оксиди утворюються в процесах технології при термічній обробці сировинних сумішей внаслідок руйнування граток породоутворюючих мінералів. Звідси витікає очевидна залежність кількості і реакційної здатності оксидів від хіміко-мінералогічного складу глинистої сировини, що по суттєвим відмінностям класифікується на ряд груп [8]. Поглиблення наукових уявлень про вказану залежність може стати додатковим фактором вдосконалення ті інтенсифікації технології силікатних в'яжучих речовин, що стало предметом дослідження в поданій роботі.

\section{Матеріали та методи дослідження}

Об'єктами дослідження є сировинні суміші для виготовлення цементного клінкеру на основі системи вапняк - глинистий компонент.

Для виготовлення вихідної сировинної суміші застосовані:

- вапняк Дубовецького родовища ІваноФранківської області, що промислово використовується ПАТ «Івано-Франківськцемент»;

- каолін КССК Глуховецького родовища Вінницької області $[9,10]$;
- зола виносу Бурштинської ТЕС як коригуюча добавка [11].

За хімічним складом проба незбагаченого каоліну КССК відзначається великим вмістом $\mathrm{SiO}_{2}$ при кількісному співвідношенні $\mathrm{SiO}_{2}: \mathrm{Al}_{2} \mathrm{O}_{3}=3,6$, підвищеним вмістом лужних оксидів типу $\mathrm{R}_{2} \mathrm{O}=4,14$ мас. \%, відносно малою кількістю барвних оксидів (табл. 1). Зола виносу при меншому, ніж КССК, вмісті $\mathrm{SiO}_{2}$ та кількісному співвідношенні $\mathrm{SiO}_{2}: \mathrm{Al}_{2} \mathrm{O}_{3}=2,6$ відзначається підвищеною концентрацією оксидів заліза.

За мінералогічним складом каолін КССК крім каолініту відзначається підвищеним вмістом кварцу та польового шпату (рис. 1).

Зола виносу характеризується наявністю склофази та кристалічних фаз, головним чином - кварцу, муліту.

\section{Результати та їх обговорення}

Отримані із застосуванням нової комп'ютерної програми «КЛІНКЕР» [12], розрахункові дані свідчать, що концентрація глинистого компоненту у бінарних сумішах залежить від його різновиду та заданого коефіцієнту насичення (КН) клінкеру. При цьому має місце зворотно пропорційна залежність концентрації глинистих від КН (рис. 2).

Так, в інтервалі КН від 0,80 до 0,95 можливий вміст кривинської глини у бінарних сумішах на основі дубовецького вапняку змінюється від 21,3 до 18,5 мас. \%, каоліну КССК - від.18,8 до 16,3 мас. \%.

Із зміною різновиду та концентрації глинистого компоненту у бінарних сумішах пов'язані відмінності характеристик портландцементного клінкеру (рис. 3).

Так, в інтервалі КН від 0,80 до 0,95 кремнеземний модуль клінкеру $\mathrm{n}$ при застосуванні кривин-

Таблиця 1.

Хімічний склад сировини

\begin{tabular}{|c|c|c|c|c|c|c|c|c|c|c|}
\hline \multirow{2}{*}{$\begin{array}{c}\text { Назва } \\
\text { проби }\end{array}$} & \multicolumn{8}{|c|}{ Вміст оксидів, мас. \% } \\
\cline { 2 - 14 } & $\mathrm{SiO}_{2}$ & $\mathrm{Al}_{2} \mathrm{O}_{3}$ & $\mathrm{Fe}_{2} \mathrm{O}_{3}$ & $\mathrm{TiO}_{2}$ & $\mathrm{CaO}$ & $\mathrm{MgO}$ & $\mathrm{SO}_{3}$ & $\mathrm{Na}_{2} \mathrm{O}$ & $\mathrm{K}_{2} \mathrm{O}$ & в.п.п \\
\hline вапняк & 3,13 & 0,06 & 1,05 & - & 52,82 & 0,52 & 0,10 & - & - & 42,32 \\
\hline КССК & 69,48 & 19,27 & 0,32 & 0,33 & 0,31 & 0,65 & 0,17 & 0,60 & 3,54 & 5,25 \\
\hline зола-виносу & 46,12 & 18,00 & 22,17 & 1,78 & 4,03 & 1,46 & 0,21 & - & 2,10 & 1,49 \\
\hline
\end{tabular}




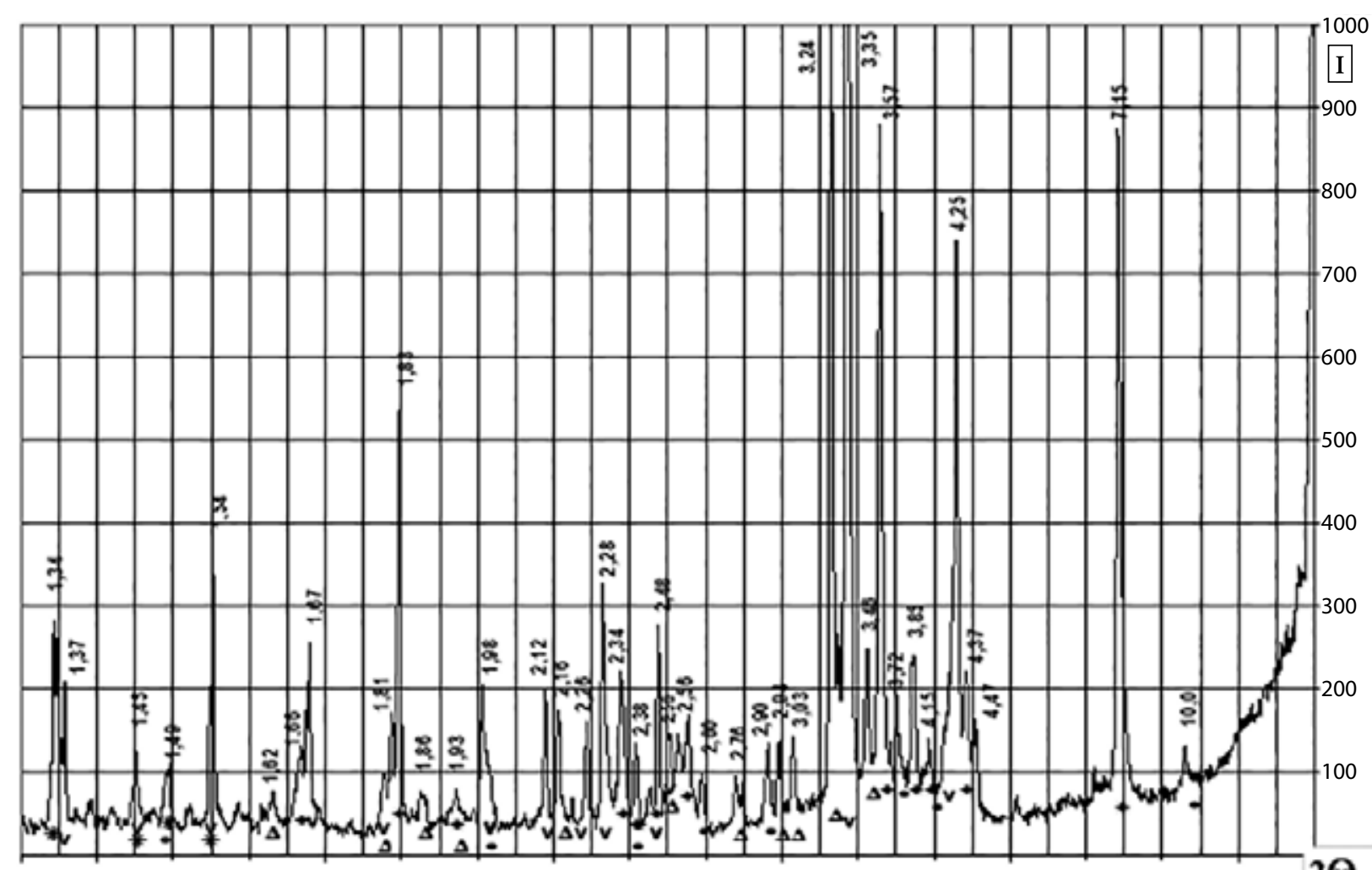

$\begin{array}{llllllllllllllllllllllllllllllllllll}70 & 68 & 66 & 64 & 62 & 60 & 58 & 56 & 54 & 52 & 50 & 48 & 46 & 44 & 42 & 40 & 38 & 36 & 34 & 32 & 30 & 28 & 26 & 24 & 22 & 20 & 18 & 16 & 14 & 12 & 10 & 8 & 6 & 4 & \mathbf{2} \Theta\end{array}$

Рис. 1. Дифрактограма незбагаченого каоліну КССК Глуховецького родовища

Позначення: v - кварц, * - каолініт, • - гідрослюда, D - польовий шпат

ської глини знаходиться на рівні 2,86 - 2,85, при застосуванні каоліну КССК - на рівні 3,41 - 3,38. Глиноземний модуль клінкеру р при застосуванні кривинської глини - від 1,71 до 1,59, при застосуванні каоліну КССК - від 4,21 до 3,53.

Таким чином, у порівнянні $з$ рекомендованими значеннями характеристик клінкеру [13] у бінарних системах при застосуванні каоліну КССК, має місце перевищення по кремнеземному модулю (3,38 - 3,41 проти 1,90 - 3,0) та по глиноземному модулю $(3,53$ $4,21$ проти $0,90-2,0)$.

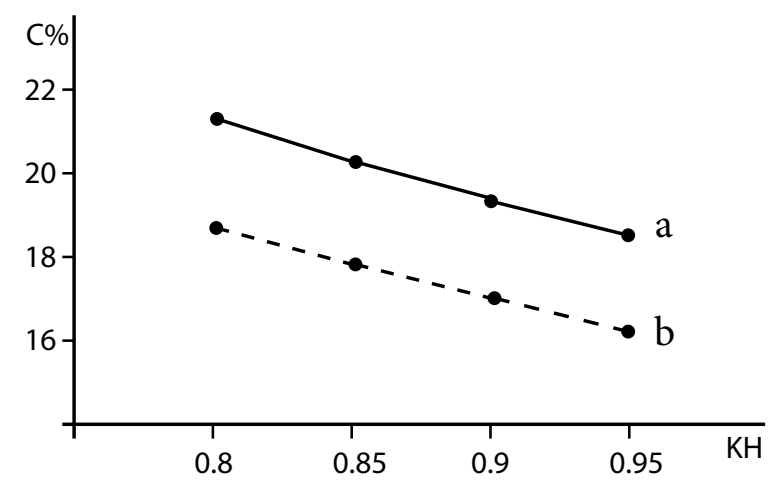

Рис. 2. Залежність вмісту глини кривинської (a) та каоліну КССК (b) у бінарній системі на основі вапняку від коефіцієнту насичення КН
Відповідно до викладеного вище аналізу для дослідження особливостей складу та властивостей цементного клінкеру при варіюванні глинистого компоненту було обрано проби сумішей 16 - 41 i 16 - 42 на основі бінарних систем та 16 - 52 - трикомпонентна із золою виносу як коригуючою добавкою (табл. 2).

Аналіз хімічного складу досліджуваних сумішей свідчать, що застосування незбагаченого каоліну (проба 16 - 42) замість полі мінеральної глини (проба 16 - 41) призводить до певного збільшення вмісту оксидів кремнію, алюмінію та кальцію при зменшенні кількісного співвідношення $\mathrm{SiO}_{2}: \mathrm{Al}_{2} \mathrm{O}_{3}$ від 4,6 до 4,3, $\mathrm{CaO}: \mathrm{Al}_{2} \mathrm{O}_{3}$ від 13,5 до 12,6 при зменшенні вмісту $\mathrm{Fe}_{2} \mathrm{O}_{3}$ i $\mathrm{MgO}$ (табл. 3.). Вказана тенденція підсилюється у випадку 3-компонентної суміші iз заміною частини каоліну на золу виносу (проба 16 - 52): подальше зменшення кількісного співвідношення $\mathrm{SiO}_{2}: \mathrm{Al}_{2} \mathrm{O}_{3}$ до 4,0; $\mathrm{CaO}: \mathrm{Al}_{2} \mathrm{O}_{3}$ до 11,8. Однак при цьому має місце деяке збільшення кількісного співвідношення $\mathrm{CaO}: \mathrm{SiO}_{2}$ від 2,9 до 3,0 та вмісту $\mathrm{Fe}_{2} \mathrm{O}_{3}$ i $\mathrm{MgO}$.

Зміни хімічного складу клінкера відповідають вказаному складу вихідних сировинних сумішей та обумовлюють характерники та фазовий склад матеріалу після випалу (табл. 4, 5). Так, за розра- 


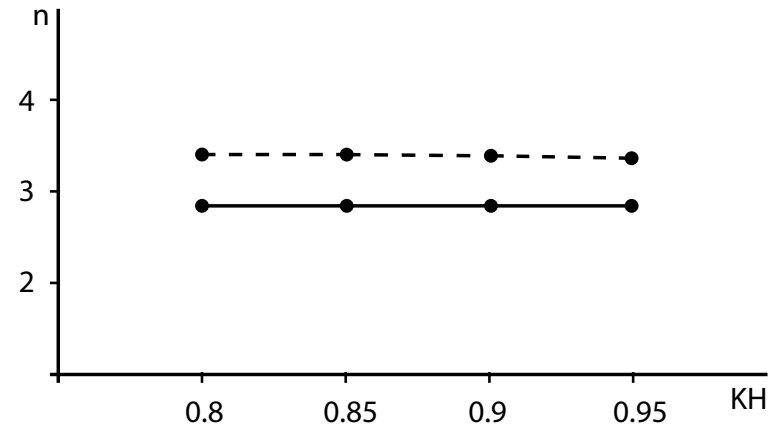

a)

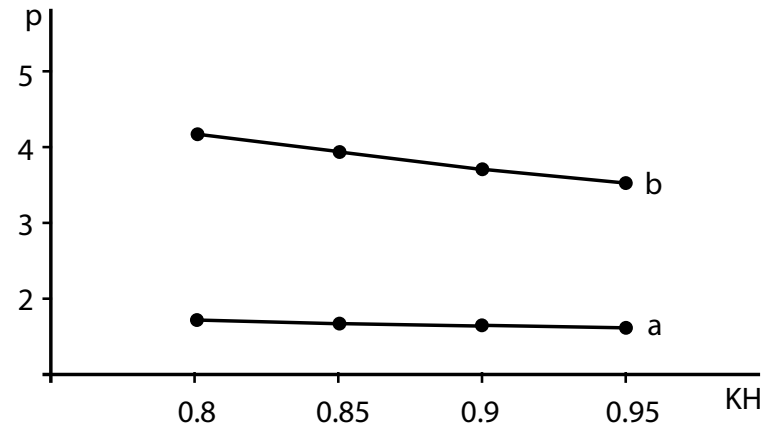

б)

Рис. 3. Залежність кремнеземного (1) та глиноземного (2) модулів n від коефіцієнту насичення КН у бінарній системі: кривинська (а), каолін КССК (б)

Таблиця 2.

Склад сумішей для виготовлення клінкеру

\begin{tabular}{|c|c|c|c|c|}
\hline \multirow{2}{*}{ Код суміші } & \multicolumn{3}{|c|}{ Вміст компонентів, мас. \% } \\
\cline { 2 - 5 } & Вапняк & $\begin{array}{c}\text { Глина } \\
\text { кривинська }\end{array}$ & $\begin{array}{c}\text { Каолін } \\
\text { КССК }\end{array}$ & $\begin{array}{c}\text { 3ола ви- } \\
\text { носу }\end{array}$ \\
\hline $16-41$ & 80,5 & 19,5 & - & - \\
\hline $16-42$ & 83,0 & - & 17,0 & - \\
\hline $16-52$ & 82,0 & - & 13,0 & 5,0 \\
\hline
\end{tabular}

Таблиця 3.

Хімічний склад сировинних сумішей

\begin{tabular}{|c|c|c|c|c|c|c|c|}
\hline \multirow{2}{*}{$\begin{array}{c}\text { Код } \\
\text { проби }\end{array}$} & \multicolumn{7}{|c|}{ Вміст оксидів, мас. \% } \\
\cline { 2 - 8 } & $\mathrm{SiO}_{2}$ & $\mathrm{Al}_{2} \mathrm{O}_{3}$ & $\mathrm{Fe}_{2} \mathrm{O}_{3}$ & $\mathrm{CaO}$ & $\mathrm{MgO}$ & $\mathrm{SO}_{3}$ & в.п.п \\
\hline $16-41$ & 14.79 & 3.20 & 1.97 & 43.27 & 0.83 & 0.11 & 35.83 \\
\hline $16-42$ & 15.00 & 3.49 & 0.93 & 43.87 & 0.55 & 0.11 & 36.05 \\
\hline $16-52$ & 14.55 & 3.67 & 2.15 & 43.49 & 0.60 & 0.11 & 35.43 \\
\hline
\end{tabular}

Таблиця 4.

Хімічний склад клінкеру

\begin{tabular}{|c|c|c|c|c|c|c|}
\hline \multirow{2}{*}{ Код проби } & \multicolumn{6}{|c|}{ Вміст оксидів, мас. \% } \\
\hline & $\mathrm{SiO}_{2}$ & $\mathrm{Al}_{2} \mathrm{O}_{3}$ & $\mathrm{Fe}_{2} \mathrm{O}_{3}$ & $\mathrm{CaO}$ & $\mathrm{MgO}$ & $\mathrm{SO}_{3}$ \\
\hline $16-41$ & 23,05 & 4,98 & 3,07 & 67,44 & 1,29 & 0,17 \\
\hline $16-42$ & 23,46 & 5,45 & 1,46 & 68,60 & 0,86 & 0,17 \\
\hline $16-2$ & 22,53 & 5,69 & 3,33 & 67,35 & 0,93 & 0,17 \\
\hline
\end{tabular}


ISSN 2521-6694 (Print) Ceramics: science and life, 2(39), 2018

Таблиця 5.

Розрахункові характеристики клінкеру

\begin{tabular}{|c|c|c|c|c|c|c|c|}
\hline \multirow{2}{*}{ Код проби } & \multicolumn{3}{|c|}{ Характеристики клінкеру } & \multicolumn{4}{|c|}{ Вміст $\mathrm{C}_{2} \mathrm{~S}$ кристалічних фаз, \% } \\
\hline & KH & $\mathrm{n}$ & $\mathrm{p}$ & $\mathrm{C}_{3} \mathrm{~S}$ & $\mathrm{C}_{2} \mathrm{~S}$ & $\mathrm{C}_{3} \mathrm{~A}$ & $\mathrm{C}_{4} \mathrm{AF}$ \\
\hline $16-41$ & 0,90 & 2,86 & 1,62 & 58,65 & 18,96 & 2,36 & 7,60 \\
\hline $16-42$ & 0,90 & 3,40 & 3,73 & 59,74 & 19,32 & 11,97 & 4,44 \\
\hline $16-52$ & 0,90 & 2,50 & 1,71 & 57,27 & 18,52 & 9,44 & 10,12 \\
\hline
\end{tabular}

Таблиця 6.

Властивості в'яжучого матеріалу

\begin{tabular}{|c|c|c|c|c|}
\hline \multirow{2}{*}{\multicolumn{2}{|c|}{ Показники }} & \multicolumn{3}{|c|}{ Код проби } \\
\hline & & $16-41$ & $16-42$ & $16-52$ \\
\hline \multicolumn{2}{|c|}{ Тонкість помелу, залишок на ситі 008, мас. \% } & 13 & 13 & 13 \\
\hline \multirow{2}{*}{ Терміни тужавлення, хв. } & початок & 45 & 10 & 50 \\
\hline & кінець & 85 & 20 & 65 \\
\hline \multicolumn{2}{|c|}{ Міцність на стиск через 28 діб, МПа } & 38,0 & 36,5 & 38,5 \\
\hline
\end{tabular}

хунками прогнозний фазовий склад проби 16 - 42 відрізняється від проби 16 - 41 більшим утворенням кристалічних фаз алюмінатів кальцію типу $\mathrm{C}_{3} \mathrm{~A}(12,4$ проти 2,4 \%) і суттєвим зменшенням $\mathrm{C}_{4} \mathrm{AF}(4,4$ проти 7,6).

У випадку проби 16 - 52 прогнозується одночасне збільшення вмісту кристалічних фаз $\mathrm{C}_{3} \mathrm{~A}$ та $\mathrm{C}_{4} \mathrm{AF}$.

Рентгенофазовий аналіз, проведений за допомогою дифрактометра ДРОН-3М, дозволив поглибити уявлення про особливості фазових перетворень при випалі досліджуваних сумішей [14].

Після спільного випалу при максимальній температурі $1400{ }^{\circ} \mathrm{C}$ має місце руйнування кристалічних граток основних породоутворюючих мінералів сировинних компонентів із формуванням фазового складу клінкеру як фактора структури, що визначає фізико-технічні властивості цементу. При цьому встановлено, що проби випаленого матеріалу відрізняються якісним та кількісним складом кристалічних фаз (рис. 4 - 6).

Так, проба 16 - 42 із незбагаченим каоліном на відміну від 16 - 41 з полімінеральною глиною характеризується: щодо силікатів кальцію меншим розвитком кристалів воластоніту CS; щодо алюмінатів кальцію більшим розвитком майєніту $\mathrm{C}_{12} \mathrm{~A}_{7}$; щодо алюмосилікатів кальцію меншим розвитком геленіту $\mathrm{C}_{2} \mathrm{AS}$; щодо алюмінатів кремнію більшим розвитком муліту $\mathrm{A}_{3} \mathrm{~S}_{2}$. Введення золи виносу в пробі 16 -
52 обумовлює розвиток залізовмісних кристалічних фаз CF, $\mathrm{C}_{4} \mathrm{AF}$ та кварцу.

Отримані результати тестувань проб на основі досліджуваних сумішей після випалу з максимальною температурою $1400{ }^{\circ} \mathrm{C}$ свідчать про відмінності їх в'яжучих властивостей (табл. 6).

Згідно класифікації ДСТУ Б В.27-91-99 за швидкістю тужавлення проба в'яжучого 16 - 42 відноситься до групи надшвидкотужавіючих (термін початку до 15 хв.), характерними представниками якої вважаються розширювальні та напружуючий цементи.

Проби в'яжучого 16 - 41 та 16 - 52 відносяться до групи нормальнотужавіючих (термін початку від 45 хв. до 2 год.), характерними представником якої вважається портландцемент і шлакопортландцемент.

\section{Висновки}

1. Хіміко-мінералогічний склад глинистого компоненту вихідних сировинних сумішей для виробництва клінкеру та цементів на його основі є важливим фактором структуроутворення в'яжучого матеріалу на стадіях технологічного процесу та визначення властивостей кінцевого продукту.

2. 3 урахуванням особливості складу незбагаченого каоліну (підвищеним вмістом каолініту, 


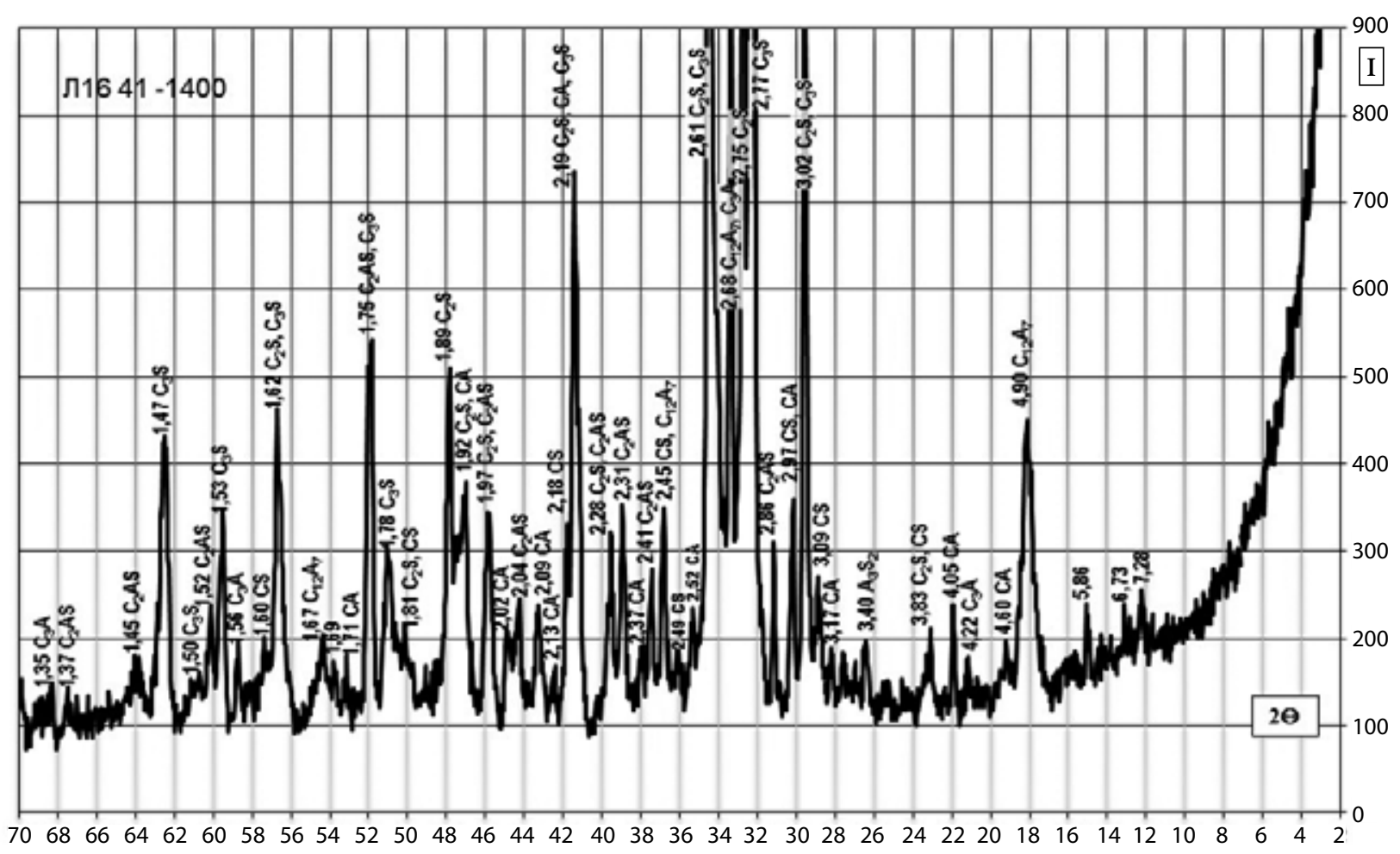

Рис. 4. Дифрактограма клінкеру з суміші $16-41$

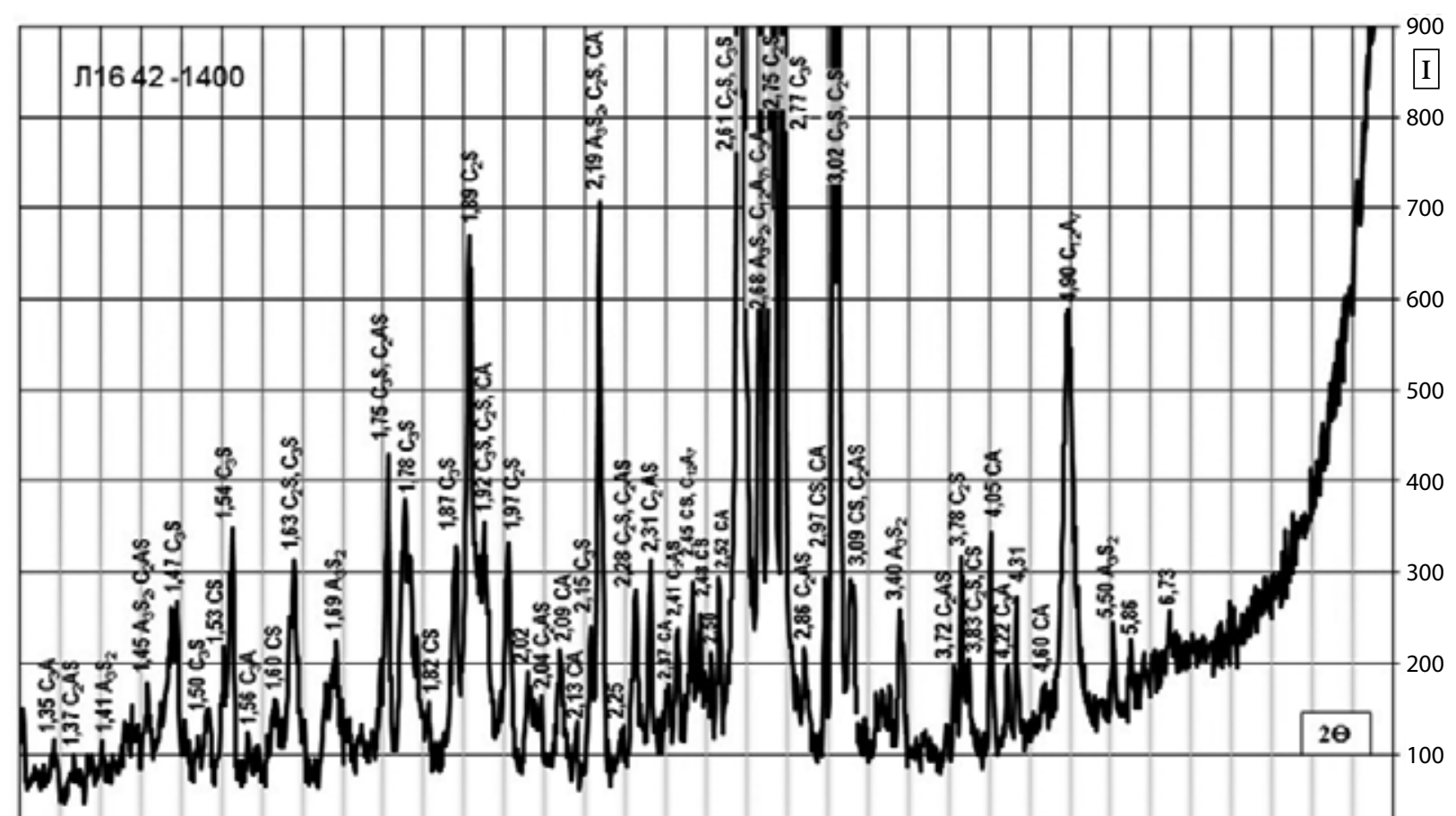

$\begin{array}{lllllllllllllllllllllllllllllllllll}70 & 68 & 66 & 64 & 62 & 60 & 58 & 56 & 54 & 52 & 50 & 48 & 46 & 44 & 42 & 40 & 38 & 36 & 34 & 32 & 30 & 28 & 26 & 24 & 22 & 20 & 18 & 16 & 14 & 12 & 10 & 8 & 6 & 4 & 2\end{array}$

Рис. 5. Дифрактограма клінкеру з суміші 16 - 42 


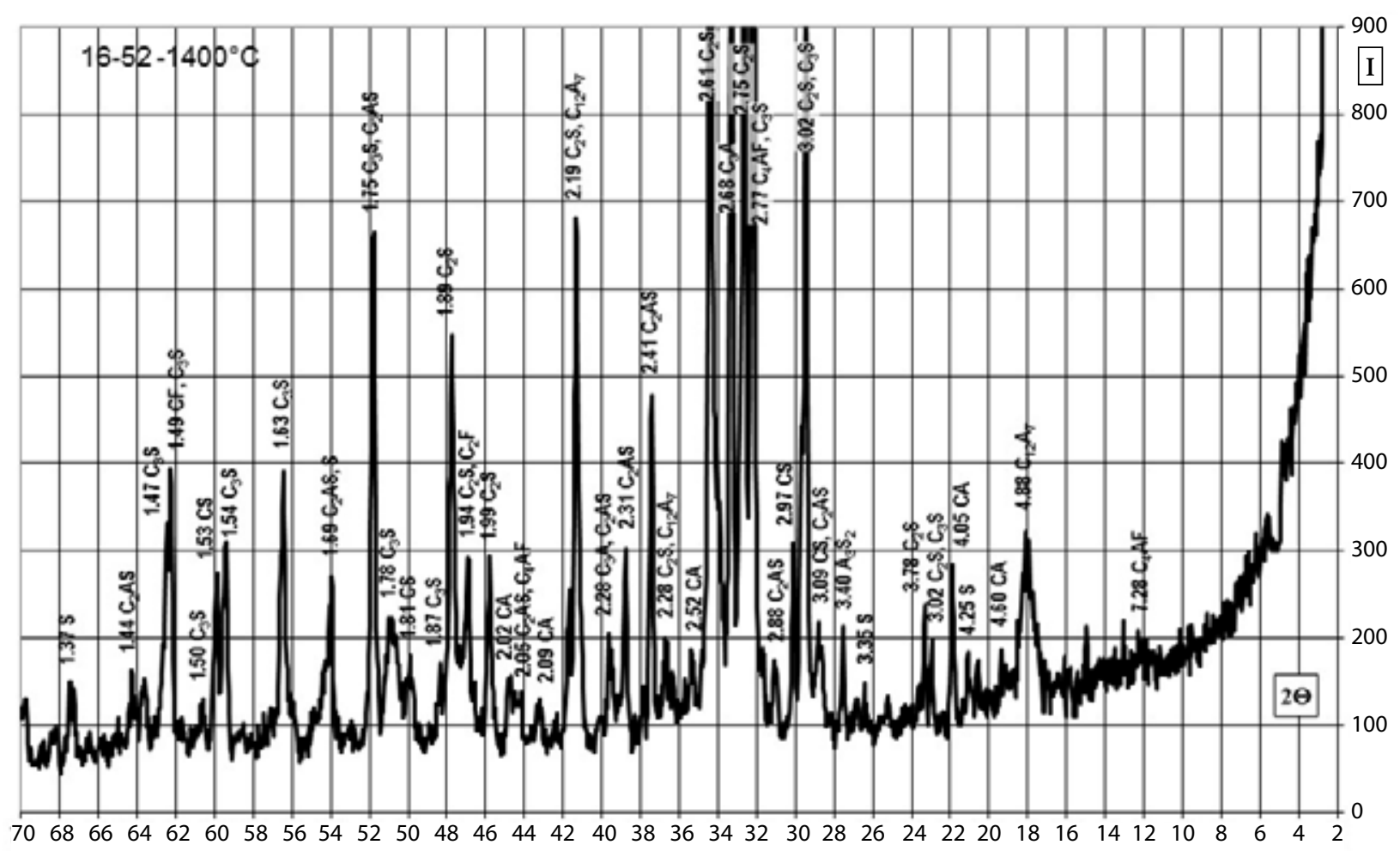

Рис. 6. Дифрактограма клінкеру з суміші 16 - 52

кварцу, польового шпату), доцільність його застосування у виробництві цементу для виготовлення клінкеру пов'язана з можливістю регулювання кінетики і напрямку фазових перетворень при випалі матеріалу.

3. 3 позицій ресурсозбереження і технології важливим $є$ показане комплексне застосування алюмо- $\mathrm{i}$ кремнеземвмісних сировинних компонентів природного (незбагачений каолін) і техногенного (зола виносу) походження.

\section{References}

1. Clays, Clay Minerals and Ceramic Materials Based on Clay Minerals. Edited by Gustavo Morari Do Nascimento - Brazil: Universidade Federal do ABC. - 2016.

2. Черняк, Л.П. Мінералогічний склад і напрямки застосування глинистої сировини // Зб. Матеріали V міжнародної науково-технічної конференції «Композиційні матеріали». - Київ: НТУ У «КПІ». - 2010. C. $30-33$.

3. Бутm, Ю.М. Химическая технология вяжущих материалов [Текст] / Ю.М. Бутт, М.М. Сычев, В.В. Тимашев. - М.: Высшая школа. - 1980. - 460 с. 4. Duda Walter H. Cement Data Book, Vol. 3: Raw Material for Cement Production - French \& European Pubns. - 1988. - 188 p.
5. Теория цемента. Под ред. А.А. Пащенко. К.: Будівельник. - 1991. - 168 с.

6. Taylor, H.F.W. Cement Chemistry / H.F.W. Taylor - London: Thomas Telford Publishing; 2 edition. 1997. -459 p.

7. Ghosh, S.N. Advances in Cement Technology: Chemistry, Manufacture and Testing/ Taylor \& Francis.2003. -828 p.

8. Winter, Nicholas B. Understanding Cement. WHD Microanalysis Consultants Ltd. - 2012. - 206 p. 9. ДСТУ Б В.2.7-60-97. Сировина глиниста для виробництва керамічних будівельних матеріалів. Класифікація. - Введ. 01.07.97. - К.: Держкоммістобудування України. - 1997. - 12 с.

10. Сальник, В.Г. Особливості застосування каолінів Глуховецького родовища в технології санітарної кераміки // Наукові вісті Національного технічного університету України "Київський політехнічний інститут”. - К.: НТУУ “КПІ”. - 2007. - № 5(47). C. $124-128$.

11. Дорогань, Н.О. Портландцементний клінкер 3 різновидами каоліну / Н.О. Дорогань, В.А. Свідерський, Л.П. Черняк // Вісник Національго технічного університету «ХПІ». - Харків: НТУ «ХПІ». 2014. - № 51(1093). - С.46 - 53.

12. Носанчук, Т.П. Зола-виносу ТЕС як компонент портландцементного клінкеру / Т.П. Носанчук, Н.О. Дорогань, Л.П. Черняк // Материалы деся- 
той Международной научно-практической конференции «Наука, образование и техника: итоги 2013 года»: - Донецк: «Аспект». - 2013. - Т. 2. C. $94-100$.

13. Свідерський, B.A. Програмне забезпечення технології портландцементу / В.А. Свідерський, Л.П. Черняк, Н.О. Дорогань, А.С. Сорока // Строительные материалы и изделия. - 2014. - № 1(84). C. $16-17$.
14. Зозуля, П.В. Проектирование цементных заводов / П.В. Зозуля, Ю.А. Никифоров. - С.-Петербург: Синтез. - 1994. - 444 с.

15. Цибенко, М.Ю. Особливості фазового складу в'яжучого матеріалу при застосуванні спондилової глини / М.Ю. Цибенко, І.А. Голоюх, Н.О. Дорогань, Л.П. Черняк // Будівельні матеріали, вироби та санітарна кераміка. - Київ. - 2015. - № 54. C. $25-30$. 